\title{
Seroepidemiological study of herpes simplex virus type 2 infection in HIV positive patients, Delhi, India, 2007
}

\section{Amit B. Karad,} Sujata L. Khade

National Center for Disease Control, Ministry of Health and Family Welfare, Government of India, Delhi, India

Address for the Correspondence: Dr. Amit B. Karad, 16/5, Second Floor, Anand Villas, Alipur Road, Civil Lines, Delhi - 110 054, India. E-mail: dr.amitkarad@gmail.com

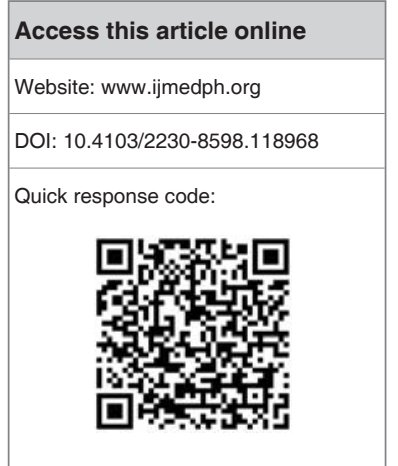

Background: Herpes simplex virus type 2 (HSV-2) infection is the primary cause of genital herpes worldwide and also has potential role in facilitating human immunodeficiency virus (HIV) transmission. Materials and Methods: In our analytical cross-sectional study we interviewed and collected serum samples from $91 \mathrm{HIV}$ positive subjects coming to antiretroviral therapy center at a government hospital in Delhi, to determine the seroprevalence and relative prevalence of HSV-2 among subjects with specific risk attributes. The patients were interviewed using a structured questionnaire and their serum samples were tested for HSV-2 specific immunoglobulin G ( $\mathrm{lgG}$ ) antibodies. We compared prevalence of HSV-2 antibodies between exposed and unexposed; to demographic, socioeconomic, and behavioral variables. Results: Fifty-two (57.1\%) male and 39 (42.9\%) female HIV positive subjects participated in the study. Seroprevalence of HSV-2 was $48.4 \%$ (males: $51.9 \%$ and females: $43.6 \%$ ). Only $4.5 \%$ had given current history of genital ulcer. Overall increasing number of lifetime sexual partners showed significant association with HSV-2 seropositivity (Chi-square for trend: 19.17; $P=0.00001$ ). Among men sexual contact with commercial sex workers (prevalence ratio $(P R)=6.6$; $95 \%$ confidence interval $(\mathrm{Cl})=1.76-24.83 ; P=0.0002)$ and age at first sexual intercourse $<19$ years ( $P R=2.3 ; 95 \% \mathrm{Cl}=0.98-5.6 ; P=0.021$ ) were significantly associated with HSV-2 seropositivity. Use of condom during sexual intercourse among men, showed significant protective effect (PR $=0.57 ; 95 \%$ $\mathrm{Cl}=0.356-0.902 ; P=0.037)$. Among women history of past genital ulcer was significantly associated ( $\mathrm{PR}=2.25 ; 95 \% \mathrm{Cl}=1.14-4.45 ; P=0.026$ ) with HSV-2 seroposititvity. Conclusions: The prevalence of HSV-2 is high in the study group with high proportions of undiagnosed HSV-2 infections. HSV type-specific serological testing in the HIV infected subpopulation should be used to diagnose HSV-2 infections and high risk groups should be targeted for interventions like behavioral intervention messages. Consistent condom use should be promoted.

Key words: Genital herpes, herpes simplex virus type 2, human immunodeficiency virus

\section{INTRODUCTION}

The HIV/AIDS is now almost 30 years old and in these 30 years, millions of people have been infected by human immunodeficiency virus (HIV). Herpes simplex virus type 2 (HSV-2) infection is one of the many infections that is impacting this HIV/AIDS epidemic.

Herpes simplex virus type 2 (HSV-2) infection is the primary cause of genital herpes and its prevalence is increasing worldwide. ${ }^{[1-3]}$ There is currently very little data available on HSV2 prevalence in different parts of the world; including Asia, South America, and Africa. The HSV-2 incidence data are also scarce. ${ }^{[4-6]}$ The public health importance of HSV-2 relates to its potential role in facilitating HIV transmission. There is increasing evidence that HSV-2 facilitates HIV transmission. ${ }^{[7]}$ A prospective study among heterosexual HIV-1 discordant couples in Rakai, Uganda, found that genital ulcer disease in the HIV-1-infected partner, primarily resulting from HSV-2, was associated with a four-fold increase in the likelihood of HIV-1 transmission. ${ }^{[8]}$ Also in countries where coinfection with HIV and HSV-2 is common, the significance of HSV-2 as a cause of ulceration has probably been underestimated. ${ }^{[9]}$ 
The HSV-2 ulceration that occurs in HIV infected individuals is frequently atypical, severe, and persistent. ${ }^{[10]}$

Given this, an approach to impacting HIV/AIDS epidemic may be to consider HSV-2 serostatus among HIV positive subjects, for the implementation of available HSV-2 control methods and the development of vaccines for HSV-2..$^{[9,11,12]}$

Seroepidemiological studies are critical to understand the pattern and distribution of HSV-2 infection within populations ${ }^{[9]}$ and help generate evidence for target (focused prevention) efforts to lower HSV-2 risk factors.

The aim of the present study was to determine the seroprevalence of HSV-2 and its association with age, sex, as well as other demographic and behavioral factors among HIV-positive patients from antiretroviral therapy center of a government hospital in the city of New Delhi, India.

\section{Objectives}

1. To estimate the seroprevalence of HSV-2 antibodies among HIV positive patients attending an antiretroviral therapy (ART) center in Delhi, India, 2007.

2. To estimate the relative prevalence of HSV-2 infection among HIV positive patients with specific characteristics attending an ART center in Delhi, India, 2007.

\section{MATERIALS AND METHODS}

In our analytical cross-sectional study we interviewed and collected serum samples from $91 \mathrm{HIV}$ positive subjects coming to ART center of a government hospital in Delhi, to determine the seroprevalence and relative prevalence of HSV-2 among subjects with specific risk attributes. The patients were interviewed using a structured questionnaire and their serum samples were tested for HSV-2 specific IgG antibodies. We compared prevalence of HSV-2 antibodies between exposed and unexposed; to demographic, socioeconomic, and behavioral variables.

\section{RESULTS}

During the study period we interviewed 98 HIV positive patients who attended the ART clinic and out of these 91 (92.9\%) agreed to participate in the study. The overall prevalence of HSV-2 antibodies among these HIV positive subjects was 48.4\% (95\% confidence interval (CI): 37.7-59.1) [Table 1]. Seroprevalence was 51.9\% (95\% CI: 37.6-66.0) among men and 43.6\% (95\% CI: 27.8-60.4) among women [Table 2].

Lifetime duration of sexual activity, educational status, gender, income status, marital status, and occupation did not appear to be associated with HSV-2 serostatus [Table 3].

With regard to exposure category having past history of genital ulcer was significantly associated with HSV-2 seropositivity (prevalence ratio (PR): 2.25 ; 95\% $\mathrm{CI}: 1.14-4.45 ; P=0.026$ ) among the male subjects. $4.5 \%$ of HSV-2 positive subjects had given current

Table 1: Prevalence of herpes simplex virus-2
(HSV-2) among HIV positive subjects
\begin{tabular}{lccc}
\hline HSV-2 status & Frequency & Percentage & 95\% confidence limits \\
\hline Positive & 44 & 48.4 & $37.7-59.1$ \\
Negative & 47 & 51.6 & $40.9-62.3$ \\
Total & 91 & 100.0 & \\
\hline
\end{tabular}

HSV=Herpes simplex virus, HIV=human immunodeficiency virus. Cross-sectional analytical study, Delhi, India, 2007

\begin{tabular}{|c|c|c|c|}
\hline Variables & $\begin{array}{c}\text { HSV-2 } \\
\text { positive } \\
n(\%)\end{array}$ & $\begin{array}{c}\text { HSV-2 } \\
\text { negative } \\
n(\%)\end{array}$ & $\begin{array}{l}\text { Total } \\
n(\%)\end{array}$ \\
\hline \multicolumn{4}{|l|}{ Occupation } \\
\hline Service & $13(29.5)$ & $18(38.3)$ & $31(34.1)$ \\
\hline Labor & $10(22.7)$ & $5(10.6)$ & $15(16.5)$ \\
\hline Others & $21(47.7)$ & $24(51.1)$ & 45 (49.5) \\
\hline \multicolumn{4}{|l|}{ Religion } \\
\hline Hindu & $43(97.7)$ & $43(91.5)$ & $86(94.5)$ \\
\hline Muslim & $1(2.3)$ & 4 (8.5) & $05(5.5)$ \\
\hline \multicolumn{4}{|l|}{ Education } \\
\hline Illiterate & $21(47.7)$ & $17(36.2)$ & $38(41.8)$ \\
\hline Primary school & 7 (15.9) & $10(21.3)$ & $17(18.7)$ \\
\hline High school & $15(34.1)$ & $18(38.3)$ & $33(36.3)$ \\
\hline College & $1(2.3)$ & $2(4.3)$ & $03(3.3)$ \\
\hline \multicolumn{4}{|l|}{ Marital status } \\
\hline Married & $42(95.5)$ & 45 (95.7) & 87 (95.6) \\
\hline Unmarried & $1(2.3)$ & 0 & $01(1.1)$ \\
\hline Divorced & $1(2.3)$ & $2(4.3)$ & $03(3.3)$ \\
\hline \multicolumn{4}{|l|}{ Sex } \\
\hline Male & $27(61.4)$ & $25(53.2)$ & $52(57.1)$ \\
\hline Female & $17(38.6)$ & $22(46.8)$ & 39 (42.9) \\
\hline \multicolumn{4}{|l|}{$\begin{array}{l}\text { Monthly family } \\
\text { income }\end{array}$} \\
\hline$<2,000$ & $1(2.3)$ & $5(10.6)$ & $6(6.6)$ \\
\hline $2,000-5,000$ & $26(59.1)$ & $29(61.7)$ & $55(60.4)$ \\
\hline $5,000-10,000$ & $13(29.5)$ & $11(23.4)$ & $24(26.4)$ \\
\hline $10,000-15,000$ & $4(9.1)$ & $2(4.3)$ & $6(6.6)$ \\
\hline$>15,000$ & 0 & 0 & 0 \\
\hline \multicolumn{4}{|l|}{$\begin{array}{l}\text { Age } \\
\text { group (years) }\end{array}$} \\
\hline $0-14$ & 0 & 0 & 0 \\
\hline $15-24$ & $2(4.5)$ & 0 & $2(2.2)$ \\
\hline $25-34$ & $36(81.8)$ & $40(85.1)$ & $76(83.5)$ \\
\hline $35+$ & $6(13.6)$ & 7 (14.9) & $13(14.3)$ \\
\hline
\end{tabular}

Cross-sectional analytical study, Delhi, India, 2007

history of genital ulcer, but was not significantly associated with the HSV-2 positivity $(P=0.23)$ [Table 4]. $59.1 \%$ of the HSV-2 positive subjects were those who gave no past history of genital ulcer [Table 4]. 84.1\% of the HSV-2 positive subjects had first sexual intercourse before 19 years of age and was significantly associated with HSV-2 positivity (PR: 2.33; 95\% CI: 0.98-5.6; $P=0.021$ ) among men [Table 4].

The overall prevalence of condom use among males was $75 \%$ 


\begin{tabular}{|c|c|c|c|}
\hline Variables $n(\%)$ & $\begin{array}{c}\text { HSV-2 } \\
\text { positive } \\
n(\%) \\
\end{array}$ & $\begin{array}{c}\text { HSV-2 } \\
\text { negative } \\
n(\%)\end{array}$ & Total \\
\hline \multicolumn{4}{|c|}{ History of genital ulcer in the past } \\
\hline Yes & $18(40.9)$ & $8(17)$ & $26(28.6)$ \\
\hline No & $26(59.1)$ & $39(83)$ & $65(71.4)$ \\
\hline \multicolumn{4}{|c|}{$\begin{array}{l}\text { Currently suffering from any genital } \\
\text { ulcer disease }\end{array}$} \\
\hline Yes & $2(4.5)$ & 0 & $2(2.2)$ \\
\hline No & $42(95.5)$ & $47(100)$ & $89(97.8)$ \\
\hline \multicolumn{4}{|c|}{ Age at first sexual intercourse } \\
\hline$<19$ & $37(84.1)$ & $30(63.8)$ & $67(73.6)$ \\
\hline$\geq 19$ & $7(15.9)$ & $17(36.2)$ & $24(26.4)$ \\
\hline \multicolumn{4}{|c|}{$\begin{array}{l}\text { Use of condom during sexual } \\
\text { intercourse (Male) }\end{array}$} \\
\hline Yes & $17(63)$ & $22(88)$ & $39(75)$ \\
\hline No & $10(37)$ & $3(12)$ & $13(25)$ \\
\hline \multicolumn{4}{|c|}{ Partner condom use (Female) } \\
\hline Yes & $8(47.1)$ & $16(72.7)$ & $24(61.5)$ \\
\hline No & $9(52.9)$ & $6(27.3)$ & $15(38.5)$ \\
\hline \multicolumn{4}{|c|}{$\begin{array}{l}\text { Frequency of condom use } \\
\text { (male+partner condom use female) }\end{array}$} \\
\hline Always/regular & $12(34.3)$ & $17(41.5)$ & $29(38.2)$ \\
\hline Occasional & $13(37.1)$ & $21(51.2)$ & $34(44.7)$ \\
\hline Never & $10(28.6)$ & $3(7.3)$ & $13(17.1)$ \\
\hline \multicolumn{4}{|c|}{ Number of lifetime sexual partners } \\
\hline$\geq 3$ & $28(63.6)$ & $11(23.4)$ & $39(42.9)$ \\
\hline$<3$ & $16(36.4)$ & $36(76.6)$ & $52(57.1)$ \\
\hline \multicolumn{4}{|c|}{ Life time duration of sexual activity } \\
\hline$>10$ & $30(68.2)$ & $33(70.2)$ & $63(69.2)$ \\
\hline$\leq 10$ & $14(31.8)$ & $14(29.8)$ & $28(30.8)$ \\
\hline \multicolumn{4}{|c|}{$\begin{array}{l}\text { Sexual contact with commercial } \\
\text { sex workers }\end{array}$} \\
\hline Yes & $25(56.8)$ & $9(19.1)$ & $34(37.4)$ \\
\hline No & $19(43.2)$ & $38(80.9)$ & $57(62.6)$ \\
\hline \multicolumn{4}{|c|}{ Men having Sex with men } \\
\hline Yes & $9(33.3)$ & $1(4)$ & $10(19.2)$ \\
\hline No & $18(66.7)$ & $24(96)$ & $42(81.8)$ \\
\hline
\end{tabular}

and prevalence of condom use among HSV-2 positive males was $63 \%$. Use of condom during sexual intercourse by male subjects showed significant protective effect (PR: 0.57; 95\% CI: 0.356-0.902; $P=0.037$ ) against HSV-2 infection [Table 4]. Use of condom by sexual partners of females showed a protective effect (PR: 0.56) against HSV-2 infection, but was not significantly associated $(P=0.097)$ [Table 4]. Always/regular use of condom was found to be protective as compared to occasional/never use of condom although the association was not statistically significant. (PR: 0.73; 95\% CI: 0.45-1.19; $P=0.17$ ) [Table 4]. In the present study $34.3 \%$ of the HSV-2 positive subjects or their partners always used condoms, $37.1 \%$ were those who used condoms occasionally, and $28.6 \%$ had never used [Table 3]. $63.6 \%$ of the HSV-2 positive subjects had $\geq 3$ sexual partners in their lifetime and were having 2.3-fold higher risk for HSV-2 infection than those with $<3$ sexual partners in lifetime (PR: 2.3; 95\% CI: 1.483-3.669; $P=0.0001)$. Lifetime number of sexual partners was also significantly associated with HSV-2 positivity on analysis for linear trend showing increasing prevalence ratio with increasing number of sexual partners.(Chi-square for trend: 19.17; $P=0.00001$ ) [Table 5].

$56.8 \%$ of the HSV-2 positive male subjects, have had sexual contact with commercial sex worker and were having 6.6 fold higher risk of acquiring HSV-2 infection than those who did not have sexual contact with commercial sex worker (PR: 6.6; 95\% CI: 1.76-24.83; $P=0.0002$ ) [Table 4].

\section{DISCUSSION}

The HSV-2 seroprevalence of $48.4 \%$ was observed in our study population, which is higher than that reported in antenatal clinic attendee's (7.9\%; mean age: 24.9 years), and also higher than the crude prevalence rates observed among males (10.2\%; mean age: 31.4 years) and females (14.6\%; mean age: 30.9 years) in India, ${ }^{[0]}$ supporting the strong association between the two infections. World over the prevalence is higher in women compared with men, especially among the young, ${ }^{[13]}$ In our study Seroprevalence was slightly higher among men $51.9 \%$ than women $43.6 \%$ but was not significant $(\mathrm{p}=0.28)$. HIV-HSV-2 coinfected patients may be a common source of horizontal or vertical HSV-2 transmission. Moreover, these HIV-HSV-2 coinfected individuals may constitute subpopulations at high risk for HIV transmission to HIV-negative exposed individuals for HSV-2 increases the risk of acquiring HIV by three times and of transmitting HIV. ${ }^{[14]}$

HIV-1-infected persons have high rates of HSV-2 infection, ranging from 50 to $90 \%$ in studies of HIV-infected populations from different parts of the world. ${ }^{[15]}$

The prevalence of HSV-2 antibody was 40.22\% in 276 patients of genital ulcers in sexually-transmitted disease (STD) patients in Nagpur. ${ }^{[16]}$ There is wide variation seen among the prevalence rates among STD clinic attendee's in different parts of the country. The prevalence rate ranges from $20.5 \%$ in Chandigarh, ${ }^{[17]} 43 \%$ in Pune, ${ }^{[18]}$ to $85 \%$ in a hospital in south India. ${ }^{[19]}$

There is very limited data on prevalence of HSV-2 among HIV patients in India. The prevalence of genital herpes among HIV patients was $28.8 \%$ in a study among STD clinic patients in JIPMER, Pondicherry. ${ }^{[20]}$ The prevalence was $20 \%$ among HIV / AIDS patients at STD Department, Government Mohan Kumar Mangalam Medical College Hospital, Salem. ${ }^{[21]}$ These rates are lower than that observed in our study.

World over the prevalence is higher in women compared with men, especially among the young. ${ }^{[1,4,14]}$ In our study seroprevalence was slightly higher among men (51.9\%) than women (43.6\%), but was not significant $(P=0.28)$. However, when man having sex with man (MSM) were excluded, the seroprevalence was $42.9 \%$ 


\begin{tabular}{|c|c|c|c|c|c|c|c|c|}
\hline & \multicolumn{6}{|c|}{ Prevalence of HSV-2 } & \multirow{3}{*}{$\begin{array}{l}\text { Prevalence } \\
\text { ratio }\end{array}$} & \multirow{3}{*}{$\begin{array}{l}\text { 95\% confidence } \\
\text { interval ( } P \text {-value from } \\
\text { Fisher's exact test) }\end{array}$} \\
\hline & \multicolumn{3}{|c|}{ Among exposed } & \multicolumn{3}{|c|}{ Among unexposed } & & \\
\hline & $n$ & Total HIV +ve & Percentage & $n$ & Total HIV +ve & Percentage & & \\
\hline \multicolumn{9}{|l|}{$\begin{array}{l}\text { History of genital ulcer in the } \\
\text { past (yes or no) }\end{array}$} \\
\hline $\mathrm{M}$ & 9 & 13 & 69.2 & 18 & 39 & 46.2 & 1.5 & $0.91-2.46(0.13)$ \\
\hline $\mathrm{F}$ & 9 & 13 & 69.2 & 8 & 26 & 30.8 & 2.25 & $1.14-4.45(0.026)$ \\
\hline $\begin{array}{l}\text { Currently suffering from genital } \\
\text { ulcer disease (yes or no) }\end{array}$ & 2 & 2 & 100 & 42 & 89 & 47.2 & 2.12 & $1.7-2.64(0.23)$ \\
\hline \multicolumn{9}{|l|}{$\begin{array}{l}\text { Age at first sexual intercourse } \\
(<19 \text { or } \geq 19)\end{array}$} \\
\hline M & 23 & 37 & 62.2 & 4 & 15 & 26.7 & 2.33 & $0.98-5.6(0.021)$ \\
\hline $\mathrm{F}$ & 14 & 30 & 46.7 & 3 & 9 & 33.3 & 1.4 & $0.51-3.81(0.38)$ \\
\hline $\begin{array}{l}\text { Use of condom during sexual } \\
\text { intercourse (male; yes or no) }\end{array}$ & 17 & 39 & 43.6 & 10 & 13 & 76.9 & 0.57 & $0.36-0.902(0.037)$ \\
\hline $\begin{array}{l}\text { Frequency of condom use } \\
\text { (always/regular vs occasional/ } \\
\text { never) }\end{array}$ & 22 & 53 & 41.5 & 13 & 23 & 56.5 & 0.73 & $0.45-1.19(0.17)$ \\
\hline \multicolumn{9}{|l|}{$\begin{array}{l}\text { Number of lifetime sexual } \\
\text { partners }(>3 \text { or }<3)\end{array}$} \\
\hline M & 21 & 30 & 70 & 6 & 22 & 27.3 & 2.57 & $1.25-5.28(0.002)$ \\
\hline $\mathrm{F}$ & 7 & 9 & 77.8 & 10 & 30 & 33.3 & 2.33 & $1.26-4.32(0.024)$ \\
\hline $\begin{array}{l}\text { Lifetime duration of sexual } \\
\text { activity ( }>10 \text { or }<10 \text { years) }\end{array}$ & 30 & 63 & 47.6 & 14 & 28 & 50 & 0.95 & $0.61-1.5(-0.506)$ \\
\hline $\begin{array}{l}\text { Sexual contact with commercial } \\
\text { sex workers (males; yes or no) }\end{array}$ & 25 & 34 & 73.5 & 2 & 18 & 11.1 & 6.6 & $1.76-24.83(-0.0002)$ \\
\hline $\begin{array}{l}\text { Men having sex with men (yes } \\
\text { or no) }\end{array}$ & 9 & 10 & 90 & 18 & 42 & 42.9 & 2.1 & $1.4-3.15(-0.008)$ \\
\hline
\end{tabular}

Cross-sectional analytical study, Delhi, India, 2007

\begin{tabular}{|c|c|c|c|}
\hline \multirow{2}{*}{$\begin{array}{l}\text { Total no. of } \\
\text { sexual partners } \\
\text { in lifetime }\end{array}$} & \multicolumn{3}{|c|}{ HSV-2 status } \\
\hline & $\begin{array}{c}\text { Positive } \\
\text { n (\%) }\end{array}$ & $\begin{array}{c}\text { Negative } \\
\text { n (\%) }\end{array}$ & $\begin{array}{l}\text { Prevalence } \\
\text { ratio }\end{array}$ \\
\hline 1 & $5(11.4)$ & $25(53.2)$ & 0.21 \\
\hline 2 & $11(25.0)$ & $11(23.4)$ & 1.07 \\
\hline 3 & $15(34.1)$ & $8(17.0)$ & 2.01 \\
\hline 4 & $2(4.5)$ & $1(2.1)$ & 2.14 \\
\hline 5 & $9(20.5)$ & $2(4.3)$ & 4.77 \\
\hline 7 & $2(4.5)$ & $0(0.0)$ & $\infty$ \\
\hline Total & $44(100.0)$ & $47(100.0 \%)$ & \\
\hline $\begin{array}{l}\text { Chi-square for } \\
\text { trend analysis }\end{array}$ & \multicolumn{3}{|c|}{ Probability } \\
\hline 19.17 & \multicolumn{3}{|c|}{0.00001} \\
\hline
\end{tabular}

among men which was slightly lower than in women, but was not significantly associated $(P=0.56)$.

Infection has been associated with younger age at first sex, ${ }^{[22]}$ increased years of sexual activity, ${ }^{[23]}$ and increasing number of lifetime partners. ${ }^{[1,4,14,22,24]}$ In our study, increasing number of lifetime sexual partners was significantly associated with HSV-2 seropositive status (Chi-square for trend: 19.17; $P=0.00001$ ) [Table 5]. 63.6\% of the HSV-2 positive subjects had $\geq 3$ sexual partners in their lifetime and were having 2.30-fold higher risk for HSV-2 infection than those with $<3$ sexual partners in lifetime.

Also, among male participants younger age at first sex was significantly associated with HSV-2 positivity. In our study, there was no association between increasing years of sexual activity and HSV-2 positive status.

History of genital herpes was obtained from $40.9 \%$ of the HSV-2 positive subjects, which indicates that a major proportion of the patients were unaware of the HSV-2 infection, suggesting that although HSV-2 antibodies were quite frequent in the study population, clinical expression of the infection was rather uncommon.

This finding is in accordance with other reports, ${ }^{[25]}$ confirming that clinical information greatly underestimates the prevalence of HSV-2 disease and underscores the importance of teaching these patients how to identify the episodes of active genital herpes and counseling them to seek healthcare for genital signs and symptoms.

Condom use offers significant protection against HSV-2 infection in susceptible subjects ${ }^{[2]}$ and in our study use of condom during sexual intercourse by male subjects showed significant protective effect (PR: 0.57; 95\% CI: 0.356-0.902; $P=0.037$ ) against HSV-2 infection. The prevalence of condom use among HSV-2 positive males was $63 \%$ which was lower than overall rate of $75 \%$ among HIV subjects. Considering this, more efforts or interventions are 
needed to promote higher usage of condoms.

Sexual contact with commercial sex workers (CSW) is a potential risk factor that influences HSV-2 transmission rates. ${ }^{[27]}$ In our study, we found strong association between HSV-2 positivity and sexual contact with CSW ( $P=0.0002)$ HSV-2 positive male subjects who have had sexual contact with CSW were having 6.6-fold higher risk of acquiring HSV-2 infection than those who did not.

We recognized some limitations to our study. The results were based on cross-sectional data from HIV-positive patients representing the more severe forms of the clinical spectrum of the disease. Nevertheless, HSV infection is thought to precede and might increase the odds of HIV infection. As a result of the interaction of those infections, the frequency and severity of genital herpes and virus shedding may be modified.

In addition to that limitation, current data are based on HIV-positive patients selected from a public hospital and may not have been representative of the HIV-positive population of the Delhi. These selection factors limit the generalizability of the estimates of HSV 2 infection rates.

This was an exploratory study based on data available from a limited number of patients. Failure of patients to provide accurate information to questions related to sexual behavior may have biased our estimates as nondifferential misclassification is more likely.

However, our study has recorded very high rate of HSV-2 infection, which may affect the natural history of HIV/AIDS and enhance the transmissibility of both virus. Further studies should clarify the implications of the coinfection for HIV patients follow-up and prognosis.

\section{ACKNOWLEDGEMENT}

Several notable persons have extended their valuable time and advice to me. I extend with gratitude my sincere thanks to Dr. R. L. Ichhpujani, Addl. Director, NCDC and Dr. B. B. Rewari, NACO for their close guidance and encouragement during my research on this topic as MPH student. Dr. K. Dwivedi, NCDC, for his help in laboratory and Mr. P. D. Dhamija, Addl. Director, NCDC, for his guidance in analysis.

\section{REFERENCES}

1. Fleming DT, McQuillan GM, Johnson RE, Nahmias AJ, Aral SO, Lee FK, et al. Herpes simplex virus type 2 in the United States, 1976 to 1994. N Engl J Med 1997;337:1105-11.

2. Halioua B, Malkin JE. Epidemiology of genital herpes-recent advances. Eur J Dermatol 1999;9:177-84.

3. O'Farrell N. Increasing prevalence of genital herpes in developing countries: implications for heterosexual HIV transmission and STI control programmes. Sex Transm Infect 1999;75:377-84.

4. Kamali A, Nunn AJ, Mulder DW, Van Dyck E, Dobbins JG, Whitworth JA. Seroprevalence and incidence of genital ulcer infection in a rural Ugandan population. Sex Transm Infect 1999;75:98-102.

5. McFarland W, Gwanzura L, Bassett MT, Machekano R, Latif AS, Ley C, et al. Prevalence and incidence of herpes simplex virus type 2 infection among male Zimbabwean factory workers. J Infect Dis 1999;180:1459-65.

6. Hayes RJ, Pujades Rodriguez MM, Obasi A, Mosha F, et al. Herpes simplex virus type 2 infection increases HIV incidence in rural Tanzania. Abstract of presentation to the ISSTDR/IUSTI Conference, Berlin,
Germany 24-27 June 2001. Int J STD AIDS 12 Suppl 2;62-3.

7. Wald A, Link K. Risk of human immunodeficiency virus infection in herpes simplex virus type 2-seropositive persons: A meta-analysis. J Infect Dis 2002;185:45-52.

8. Gray RH, Wawer MJ, Brookmeyer R, Sewankambo NK, Serwadda D, Wabwire-Mangen $\mathrm{F}$, et al. Rakai Project Team. Probability of HIV-1 transmission per coital act in monogamous, heterosexual, HIV-1-discordant couples in Rakai, Uganda. Lancet 2001;357:1149-53.

9. Cowan FM, French RS, Mayaud P, Gopal R, Robinson NJ, de Oliveira SA, et al. Seroepidemiological study of herpes simplex virus types 1 and 2 in Brazil, Estonia, India, Morocco, and Sri Lanka. Sex Transm Infect 2003;79:286-90.

10. Suligoi B, Dorrucci M, Volpi A, Andreoni M, Zerboni R, Rezza G. Italian Seroconversion Study Group. Prevalence and determinants of herpes simplex virus type 2 infection in a cohort of HIV-positive individuals in Italy. Sex Transm Dis 2002;29:665-7.

11. Corey L, Handsfield HH. Genital herpes and public health: Addressing a global problem. JAMA 2000;283:791-4.

12. WHO and UNAIDS 2001. Herpes simplex virus type 2: Programmatic and research priorities in developing countries. Report of a $\mathrm{WHO} /$ UNAIDS/LSHTM workshop. London, 14-16 February. WHO HIVAIDS/2001.05.2001.

13. Low N, Broutet N, Adu-Sarkodie Y, Barton P, Hossain M, Hawkes S. Global control of sexually transmitted infections. Lancet 2006;368:2001-16.

14. Obasi A, Mosha F, Quigley M, Sekirassa Z, Gibbs T, Munguti K, et al. Antibody to herpes simplex virus type 2 as a marker of sexual risk behaviour in rural Tanzania. J Infect Dis 1999;179:16-24.

15. Strick LB, Wald A, Celum C. Management of herpes simplex virus type 2 infection in HIV type 1-infected persons. Clin Infect Dis 2006:43:347-56.

16. Ambhore NA, Thakar YS, Gaval SR, Joshi SG, Saoji AM. Seroprevalence of herpes simplex virus type-2 (HSV-2) in STD patients with genital ulcers. Indian J Sex Trans Dis 1998;19:81-4.

17. Kumar B, Sahoo B, Gupta S, Jain R. Rising incidence of genital herpes over two decades in a sexually transmitted disease clinic in north India. J Dermatol 2002;29:74-8.

18. Reynolds SJ, Risbud AR, Shepherd ME, Zenilman JM, Brookmeyer RS, Paranjape RS, et al. Recent herpes simplex virus type 2 infection and the risk of human immunodeficiency virus type 1 acquisition in India. $\mathrm{J}$ Infect Dis 2003;187:1513-21.

19. Shivaswamy KN, Thappa DM, Jaisankar TJ, Sujatha S. High seroprevalence of HSV-1 and HSV-2 in STD clinic attendees and non-high risk controls: A case control study at a referral hospital in South India. Indian J Dermatol Venereol Leprol 2005;71:26-30.

20. Gharami RC, Garg BR, Thappa DM, Hemanth RH, Amarnath SK. Profile of sexually transmitted diseases in HIV seropositive patients. Indian J Sex Trans Dis 1999;20:12-7.

21. Jeyakumar W, Prasanna G, Thirunavukkarasu D. HSV 2 lgG, IgM, antibody markers in HIV/Aids patients. Indian J Sex Trans Dis 2005;26:78-83.

22. Austin $\mathrm{H}$, Macaluso M, Nahmias A, Lee FK, Kelaghan J, Fleenor M, et al. Correlates of herpes simplex virus seroprevalence among women attending a sexually transmitted disease clinic. Sex Transm Dis 1999;26:329-34.

23. Cowan FM, Johnson AM, Ashley R, Corey L, Mindel A. Antibody to herpes simplex virus type 2 as serological marker of sexual lifestyle in populations. BMJ 1994;309:1325-9.

24. Wald A, Koutsky L, Ashley RL, Corey L. Genital herpes in a primary care clinic. Demographic and sexual correlates of herpes simplex type 2 infections. Sex Transm Dis 1997;24:149-55.

25. van Benthem BH, Spaargaren J, van Den Hoek JA, Merks J, Coutinho RA, Prins M. European Study on the Natural History of HIV Infection in Women. Prevalence and risk factors of HSV-1 and HSV-2 antibodies in European HIV infected women. Sex Transm Infect 2001;77:120-4.

26. Wald A, Langenberg AG, Link K, Izu AE, Ashely R, Warren T, et al. Effect of condoms on reducing the transmission of herpes simplex virus type 2 from men to women. JAMA 2001;285:3100-6.

27. Wald A. Herpes simplex virus type 2 transmission: Risk factors and virus shedding.Herpes 2004;11 Suppl 3:130-7A.

How to cite this article: Karad AB, Khade SL. Seroepidemiological study of herpes simplex virus type 2 infection in HIV positive patients, Delhi, India, 2007. Int J Med Public Health 2013;3:168-72. Source of Support: Nil, Conflict of Interest: None declared. 